\title{
Compounds of Emerging Concern in the San Antonio River Basin, Texas, 2011-12
}

Broadly defined, a compound of emerging concern (CEC) is "any synthetic or naturally occurring chemical or any microorganism that is not commonly monitored in the environment but has the potential to enter the environment and cause known or suspected adverse ecological and (or) human health effects" (U.S. Geological Survey, 2016).

\section{Introduction}

The City of San Antonio and the surrounding municipalities in Bexar County, Texas, are among the fastest growing cities in the Nation (U.S. Census Bureau, 2013). Increases in residential and commercial development are changing runoff patterns and likely will increase chemical loads into streams (Ockerman and McNamara, 2003). The U.S. Geological Survey (USGS), in cooperation with the San Antonio River Authority (SARA), evaluated the concentrations and distributional patterns of selected "compounds of emerging concern" (CECs) by collecting and analyzing waterquality samples from 20 sites in the San Antonio River Basin, Tex., during 2011-12. On the basis of their chemical composition or similar uses, the CECs discussed in this fact sheet are wastewater compounds, pharmaceutical compounds (hereinafter referred to as "pharmaceuticals"), and steroidal hormone and sterol compounds (hereinafter referred to as "steroidal hormones and sterols"). The locations of the sampling sites (map identifiers EC01-EC20) are depicted in figure 1, along with graphs showing the analytical results during the first of three synoptic sampling events for a subclass of the wastewater compounds.

\section{What Is a Compound of Emerging Concern (CEC)?}

Broadly defined, a CEC is "any synthetic or naturally occurring chemical or any microorganism that is not commonly monitored in the environment but has the potential to enter the environment and cause known or suspected adverse ecological and (or) human health effects" (U.S. Geological Survey, 2016). Many CECs are known endocrine disrupters or potential human carcinogens (White and others, 1994), but the potential for individual CECs or some combination of CECs to affect human health and aquatic life remains poorly understood, and most CECs remain unregulated (U.S. Environmental Protection Agency, 2016). Data on the detection and concentration of CECs are becoming more widely available, however, thereby providing managers and policy makers with more information that may be used for water treatment and water resource management. 


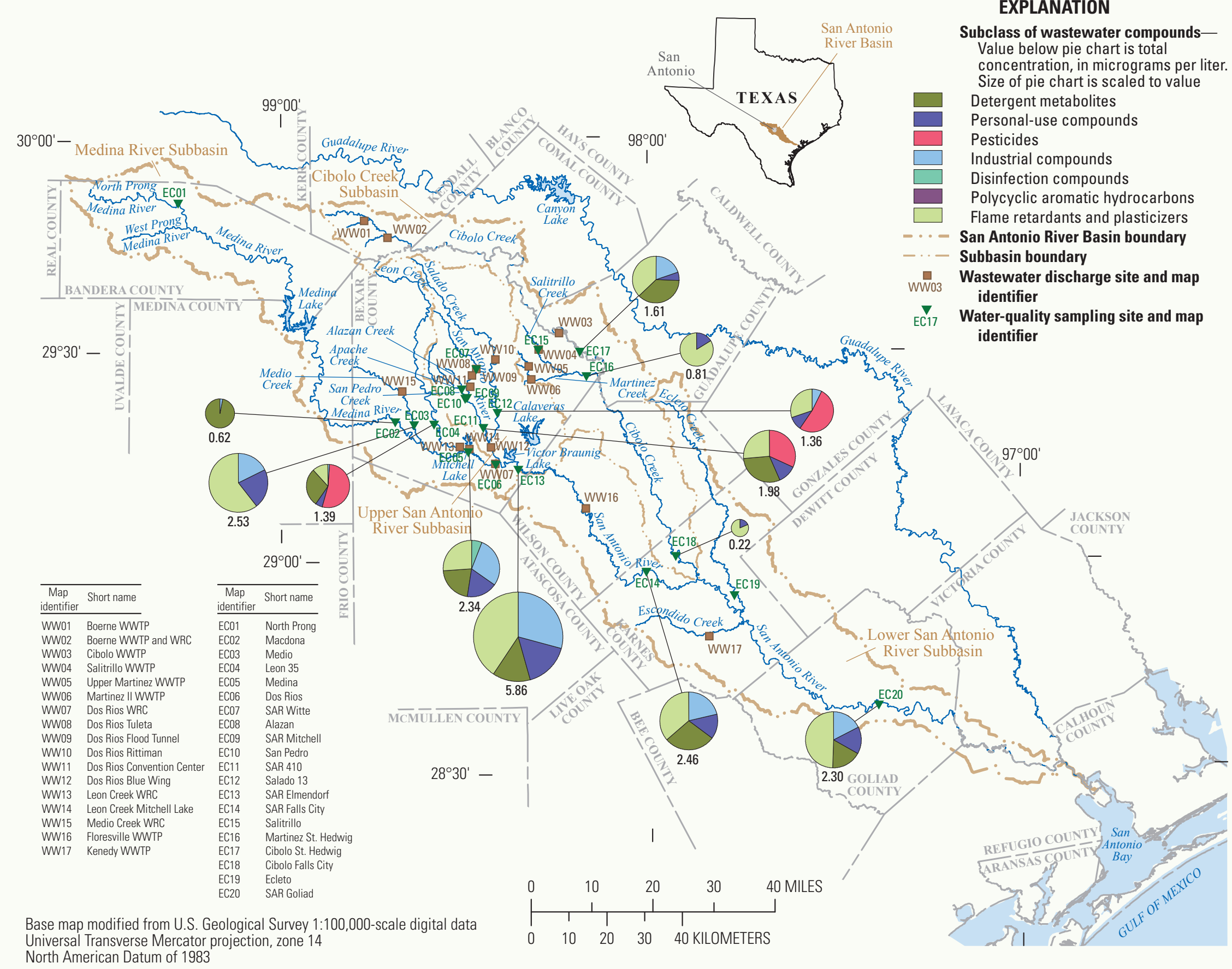

Figure 1. Locations of wastewater discharge and water-quality sampling sites (2011-12) and relative concentrations and proportions of wastewater compounds in water-quality samples collected during the first synoptic sampling event, San Antonio River Basin, Texas, March-May 2011 (modified from fig. 13, Opsahl and Lambert, 2013). 


\section{Detections and Concentrations of CECs}

Three synoptic sampling events were completed during 2011-12 to analyze for CECs in the San Antonio River Basin. During a synoptic sampling event, samples are collected from a number of sites at the same time to get a "snapshot" of how concentrations vary throughout the basin. The first and second synoptic sampling events included samples collected at the same 12 sampling sites. The third sampling event included samples collected at seven sites that were added to the study after the first two synoptic sampling events were completed. When the synoptic sampling events took place, there was no flow at the Ecleto site (EC19, fig. 1), so the samples at this rural site were collected at a separate date and time. Samples were analyzed for 54 wastewater compounds, 13 pharmaceuticals, 17 steroidal hormones, and 4 sterols. Overall, the concentrations of all CECs analyzed for during this study were low, generally close to or less than the laboratory reporting level.

\section{Wastewater Compounds}

Wastewater compounds typically found in treated domestic and industrial wastewater effluent are introduced to the environment primarily through point-source discharges from wastewater treatment plants (WWTPs) and water recycling centers (WRCs) and to a lesser degree through nonpoint sources such as seepage from septic systems, leakage from sewer lines, and urban runoff (Kolpin and others, 2004; Katz and others, 2010). During this study, wastewater compounds were aggregated into seven subclasses of compounds on the basis of similar uses or sources (fig. 2).

Wastewater compounds were detected more often than were pharmaceuticals or steroidal hormones and sterols. The subclasses of wastewater compounds that were most commonly detected were personal-use compounds, industrial compounds, and flame retardants and plasticizers. Thirty-two of the 54 compounds analyzed for were detected in at least one of the samples collected (fig. 2). The flame retardants tris (2-chloroethyl) phosphate and tris (dichloroisopropyl) phosphate were the most frequently detected wastewater compounds with measureable concentrations detected in 28 of 33 samples. Tris (2-chloroethyl) phosphate and tris (dichloroisopropyl) phosphate are possible endocrine disruptors commonly used in clothing garments, mattresses, and sofa cushions (Stapleton and others, 2009). The highest measured concentration of a wastewater compound (1.90 micrograms per liter $[\mu \mathrm{g} / \mathrm{L}]$ ) was for the fragrance hexahydrohexamethyl-cyclopentabenzopyran (HHCB); for all samples, concentrations of this compound ranged from an estimated concentration of $0.006 \mu \mathrm{g} / \mathrm{L}$ to $1.90 \mu \mathrm{g} / \mathrm{L}$. The second highest concentration of a wastewater compound measured in the study was $1.4 \mu \mathrm{g} / \mathrm{L}$ for the compound 5-methyl-1H-benzotriazole, a corrosion inhibiter used in numerous products including dishwater detergents, de-icing fluids, automotive antifreeze formulations, brake fluids, fluids for industrial cooling systems, and metal-cutting fluids (Kiss and Fries, 2009). Sample concentrations for this compound ranged from an estimated 0.1 to $1.4 \mu \mathrm{g} / \mathrm{L}$. All of the remaining wastewater compounds were measured at concentrations less than $1.0 \mu \mathrm{g} / \mathrm{L}$ or were not detected.

\section{Pharmaceuticals}

Pharmaceuticals are manufactured chemical substances administered to humans or animals to treat or prevent illness or disease or to promote the growth of food animals (Landers and others, 2012). Polar (2007, p. 7) explained that the active ingredients in pharmaceuticals "are of special concern because of the volumes introduced to the environment, their endocrine disrupting activity, and a potential increase of bacterial resistance." Pharmaceuticals and their metabolites are introduced into the environment as a component of treated wastewater effluent (Polar, 2007), direct excretion, or discharge of effluent from pharmaceutical manufacturing facilities (Phillips and others, 2010). Samples were analyzed for 13 pharmaceuticals, and 4 were detected: 1 nonprescription pharmaceutical (diphenhydramine) and 3 commonly used prescription pharmaceuticals or pharmaceutical metabolites (carbamazepine, dehydronifedipine, and sulfamethoxazole) (fig. 3). Diphenhydramine, primarily used as an antihistamine (O’Neil, 2001), was detected in 6 of 34 samples. Carbamazepine, an anticonvulsant, was the most frequently detected pharmaceutical (24 of 34 samples). Carbamazepine degrades slowly in the environment and is resistant to breakdown during water treatment (Polar, 2007; Walker and others, 2012). Dehydronifedipine is the main metabolite of nifedipine, a drug used to treat cardiac disorders (Polar, 2007); dehydronifedipine was detected in 13 of 34 samples. The antibiotic sulfamethoxazole was detected in 15 of 34 samples.

\section{Steroidal Hormones and Sterols}

Steroidal hormones and sterols are natural, biologically produced chemicals that serve a variety of functions in animal and plant metabolism. Synthetic hormone derivatives such as anabolic steroids and birth-control compounds are widely used by humans (Reif and others, 2012). Both natural and synthetic hormones can be introduced into the environment through direct excretion or disposal into wastewater treatment systems and have been detected in aquatic systems, promoting concerns about negative effects on freshwater biota (National Academy of Sciences, 1999). Eight of 17 steroidal hormones and sterols were detected in at least one of the samples collected (fig. 4). Estrone, a metabolite of 17-beta-estradiol, was the most commonly detected compound related to estrogen and was detected in 9 of 34 samples. Four plant and animal sterols were analyzed (plant sterols beta-sitosterol and beta-stigmastanol; animal sterols 3-beta-coprostanol and cholesterol), resulting in a total of 41 detections in 34 samples. Cholesterol was detected in 19 of 34 samples, making it the most frequently detected sterol.

\section{Distribution of CECs in the San Antonio River Basin}

Results from the synoptic sampling events during 2011 indicated that the number of detections and the total concentrations of CECs were higher in samples collected at sites downstream from WWTP and WRC outfalls compared to the number of detections and total concentrations measured in samples collected at other sampling sites in the study area. Among all of the sampling sites, the highest number of detections and concentrations of CECs were measured in the sample collected at the SAR Elmendorf site (EC13, fig. 1) 


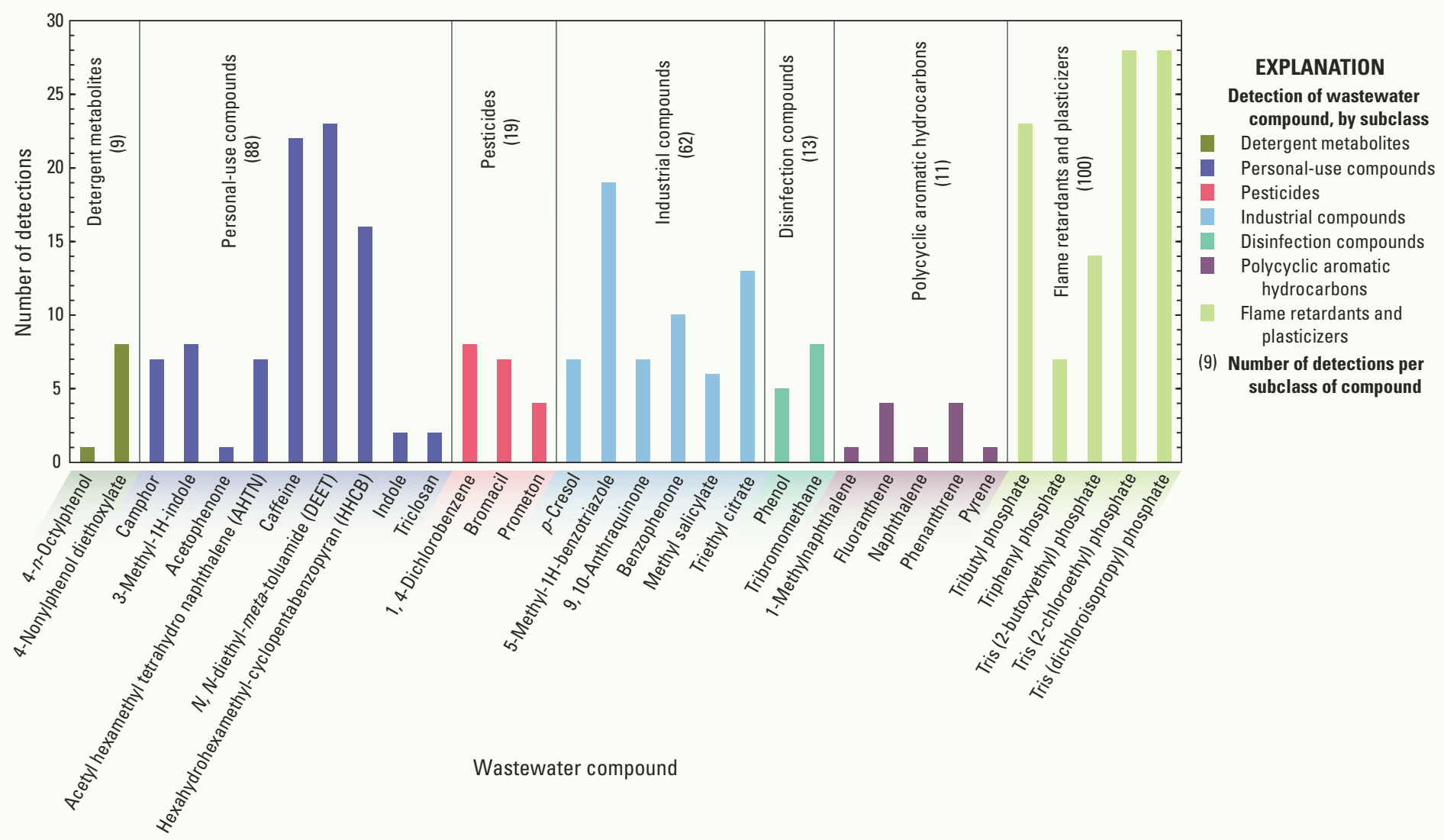

Figure 2. Wastewater compounds detected in 33 water-quality samples collected from the San Antonio River Basin, Texas, 2011-12 (modified from fig. 2, Opsahl and Lambert, 2013).

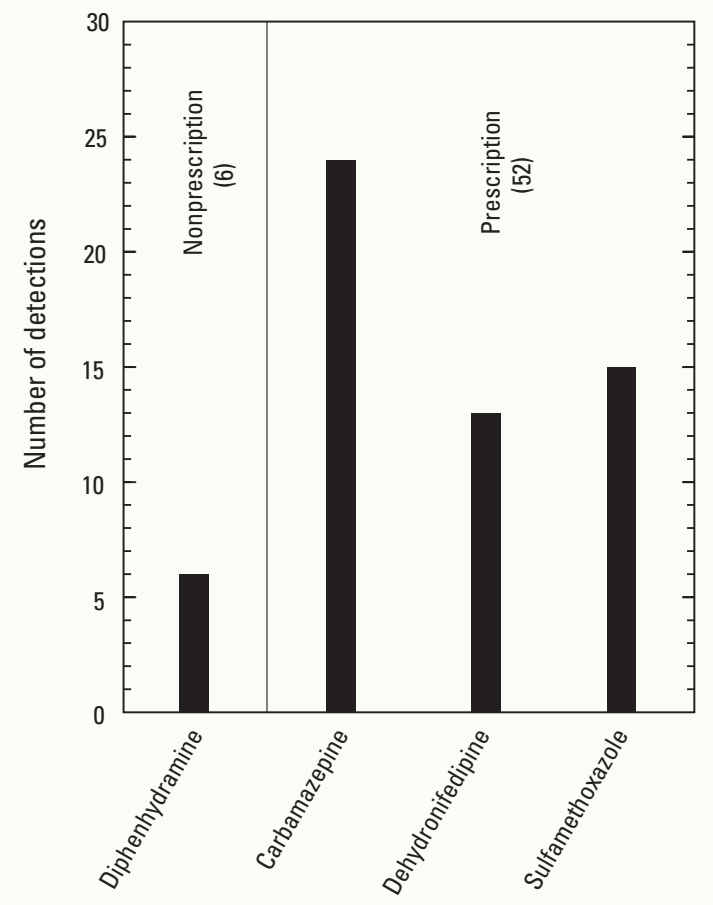

Pharmaceutical compound

EXPLANATION

$\begin{array}{lc}\begin{array}{l}\text { Detection of } \\ \text { pharmaceutical } \\ \text { compound }\end{array} & \begin{array}{c}\text { (52) } \\ \text { Number of detections } \\ \text { per subclass of } \\ \text { compound }\end{array}\end{array}$

Figure 3. Pharmaceutical compounds detected in 34 water-quality samples collected from the San Antonio River Basin, Texas, 2011-12 (modified from fig. 3, Opsahl and Lambert, 2013).

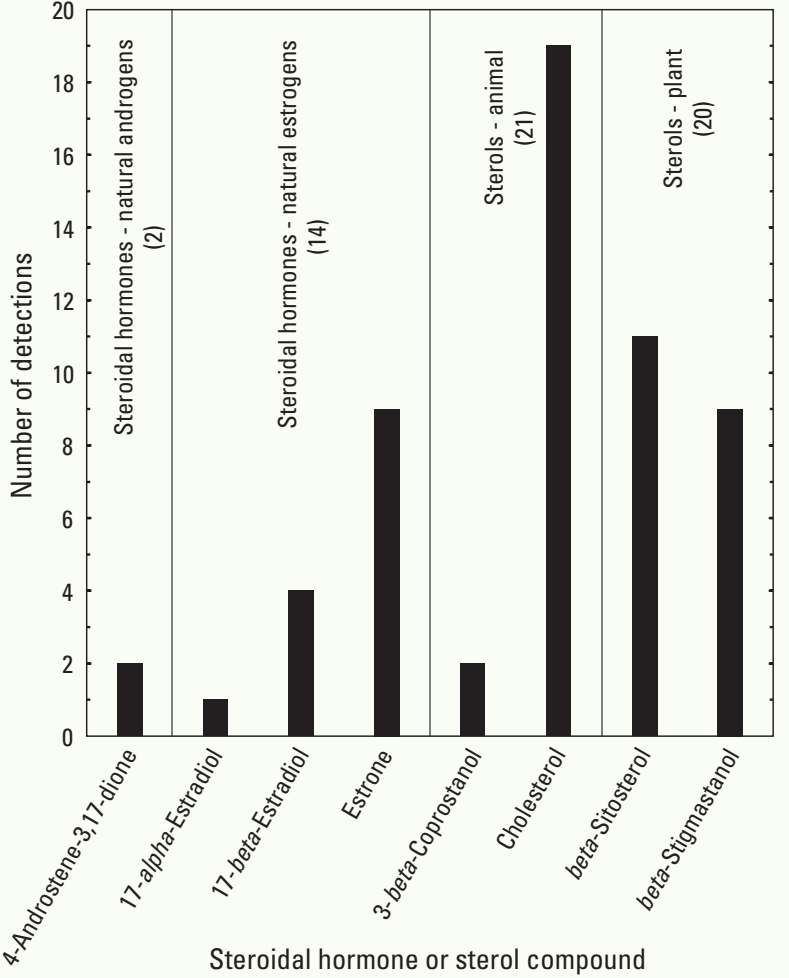

EXPLANATION

$\begin{aligned} & \text { Detection of steroidal } \\ & \text { hormone or sterol }\end{aligned}$
(21) Number of detections
compound

Figure 4. Steroidal hormones and sterols detected in 34 waterquality samples collected from the San Antonio River Basin, Texas, 2011-12 (modified from fig. 4, Opsahl and Lambert, 2013). 
downstream from San Antonio. There also were detections of CECs in samples collected from urban sites with no large upstream source of treated wastewater; these detected CECs included 1,4-dicholorobenzene, $p$-cresol, phenol, acetyl hexamethyl tetrahydro naphthalene (AHTN), HHCB, tributyl phosphate, triethyl citrate, and triphenyl phosphate. Detections of these compounds indicate that many CECs can be present in streams flowing through urbanized areas without a large upstream source of treated wastewater. The presence of wastewater compounds at the Ecleto site (EC19, fig. 1) indicates that at least some wastewater compounds can be introduced into surface waters in rural parts of the San Antonio River Basin during runoff or by seepage from onsite wastewater treatment systems.

Few pharmaceuticals were detected in samples from streams without upstream outfalls of treated wastewater. The lower concentrations of these compounds at the furthest downstream sampling sites in the basin also indicate that some dilution or natural attenuation of pharmaceuticals may occur during transport. Because the Ecleto site (EC19, fig. 1) is in a rural rangeland area that does not receive runoff from San Antonio, the steroidal hormones and sterols detected in the sample collected at this site likely were derived from cattle waste rather than from wastewater effluent.

\section{References Cited}

Katz, B.G., Griffin, D.W., McMahon, P.B., Harden, H., Wade, E., Hicks, R.W., and Chanton, J.P., 2010, Fate of effluentborne contaminants beneath septic tank drainfields overlying a karst aquifer: Journal of Environmental Quality, v. 39, p. 1181-1195.

Kiss, A., and Fries, E., 2009, Occurrence of benzotriazoles in the rivers Main, Hengstbach, and Hegbach (Germany): Environmental Science and Pollution Research, v. 16, no. 6, p. $702-710$.

Kolpin, D.W., Skopec, M., Meyer, M.T., Furlong, E.T., and Zaugg, S.D., 2004, Urban contribution of pharmaceuticals and other organic wastewater contaminants to streams during differing flow conditions: Science of the Total Environment, v. 328, p. 119-130.

Landers, T.F., Cohen, Bevin, Wittum, T.E., and Larson, E.L., 2012, A review of antibiotic use in food animals - Perspective, policy, and potential: Public Health Reports, v. 127, p. 4-22, accessed July 27, 2016, at http://www.ncbi.nlm.nih.gov/pmc/ articles/PMC3234384/pdf/phr12700004.pdf.

National Academy of Sciences, 1999, Hormonally active agents in the environment: Washington, D.C., National Academy Press, $430 \mathrm{p}$.

Ockerman, D.J., and McNamara, K.C., 2003, Simulation of streamflow and estimation of streamflow compound loads in the San Antonio River watershed, Bexar County, Texas, 19972001: U.S. Geological Survey Water Resources Investigations Report 2003-4030, 44 p.
O’Neil, M.J., ed., 2001, The Merck index-An encyclopedia of chemicals, drugs, and biologicals (13th ed.): Whitehouse Station, N.J., Merck and Company, Inc., 1,735 p.

Opsahl, S.P., and Lambert, R.B., 2013, Detections, concentrations, and distributional patterns of compounds of emerging concern in the San Antonio River Basin, Texas, 2011-12: U.S. Geological Survey Scientific Investigations Report 2013-5200, 44 p. [Also available at http://dx.doi. org/10.3133/sir20135200.]

Phillips, P.L., Smith, S.G., Kolpin, D.W., Zaugg, S.D., Buxton, H.T., Furlong, E.T., Esposito, K., and Stinson, B., 2010, Pharmaceutical formulation facilities as sources of opioids and other pharmaceuticals to wastewater treatment plant effluents: Environmental Science and Technology, v. 44, no. 13, p. 4910-4916.

Polar, J.A., 2007, The fate of pharmaceuticals after wastewater treatment: Florida Water Resources Journal, p. 26-31. [Also available at https://www.fwrj.com/TechArticle07/0607\%20 FWRJ_tech1.pdf.]

Reif, A.G., Crawford, J.K., Loper, C.A., Proctor, Arianne, Manning, Rhonda, and Titler, Robert, 2012, Occurrence of pharmaceuticals, hormones, and organic wastewater compounds in Pennsylvania waters, 2006-09: U.S. Geological Survey Scientific Investigations Report 2012-5106, 99 p.

Stapleton, H.M., Klosterhaus, Susan, Eagle, Sarah, Fuh, Jennifer, Meeker, J.D., Blum, Arlene, and Webster, T.F., 2009, Detection of organophosphate flame retardants in furniture foam and U.S. house dust: Environmental Science and Technology, v. 43, no. 19, p. 7490-7495, accessed July 29, 2016, at http://pubs.acs.org/doi/full/10.1021/ es 9014019 ? $\mathrm{src}=$ recsys.

U.S. Census Bureau, 2013, Texas cities lead Nation in population growth, Census Bureau reports: Accessed June 21, 2016, at https:/www.census.gov/newsroom/pressreleases/2013/cb13-94.html.

U.S. Environmental Protection Agency, 2016, Endocrine disruption: Endocrine Disruptor Screening Program (EDSP), accessed August 21, 2016, at https://www.epa.gov/endocrinedisruption.

U.S. Geological Survey, 2016, Contaminants of emerging concern in the environment: U.S. Geological Survey Toxic Substances Hydrology Program, accessed July 22, 2016, at http://toxics.usgs.gov/regional/emc/.

Walker, C.W., Watson, J.E., and Williams, C., 2012, Occurrence of carbamazepine in soils under different land uses receiving wastewater: Journal of Environmental Quality, v. 41, no. 4, p. 1263-1267, accessed August 19, 2013, at http://www.ncbi. nlm.nih.gov/pubmed/22751070.

White, Robert, Jobling, Susan, Hoare, S.A., Sumpter, J.P., and Parker, M.G., 1994, Environmentally persistent compounds are estrogenic: Endocrinology, v. 135, no. 1, p. 175-182. 
This fact sheet is based on the following report:

Opsahl, S.P., and Lambert, R.B., 2013, Detections, concentrations, and distributional patterns of compounds of emerging concern in the San Antonio River Basin, Texas, 2011-12: U.S. Geological Survey Scientific Investigations Report 2013-5200, 44 p., http://dx.doi.org/10.3133/ sir20135200.

By Rebecca B. Lambert and Stephen P. Opsahl
Front page photograph: View of the San Antonio River oriented upstream in San Antonio, Texas (photograph taken on November 14, 2013, by Michael B. Nyman, U.S. Geological Survey; from Opsahl and Lambert, 2013).

Back page photograph: U.S. Geological Survey hydrographers collecting water sample for analysis of compounds of emerging concern (photograph taken on May 31, 2011, by Chiquita S. Lopez, U.S. Geological Survey; from Opsahl and Lambert, 2013).

\author{
For more information, please contact: \\ Director, Texas Water Science Center \\ U.S. Geological Survey \\ 1505 Ferguson Lane \\ Austin, TX 78754-4501 \\ http://tx.usgs.gov/
}

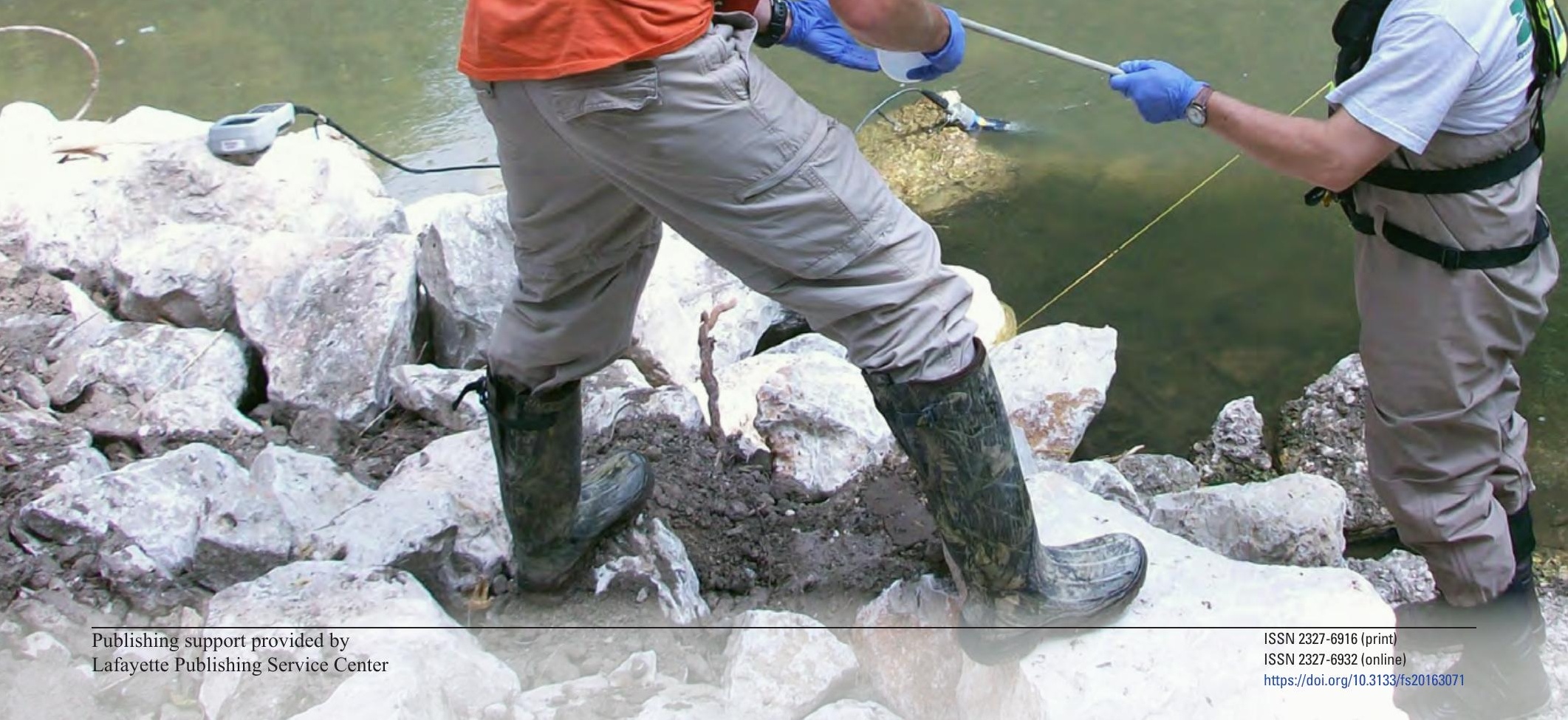

